
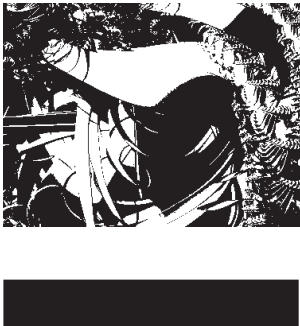

\title{
VRTLOG NOVOGA SVIJETA
}

Mauro DUJMOVIĆ

Sveučilište Jurja Dobrile u Puli, Pula

UDK: 316.77

$316.728: 366$

Pregledni rad

Primlieno: 26. 6. 2009.

Aldous Huxley napisao je roman Vrli novi svijet 1932. godine, dok je George Orwell napisao svoj roman 1984. negdje između 1945. i 1948. godine. Izrazit očaj, krainii pesimizam i besperspektivnost čovjekove sadašnjosti i budućnosti glavne su odlike ovih romana, a upozorenje se odnosi na činjenicu da ako se u tijeku povijesti i razvoja ljudskoga društva nešto ne promijeni, liudi će širom svijeta izgubiti većinu svojih liudskih obiliežja i postati automati bez duše, a da toga neće biti ni svjesni. U Vrlom novom svijetu utjecaj medija na liude toliko je očit da stanovništvo nesvjesno upotrebljava komercijalni jezik oglašavanja u svom govoru. Orwell je precizno anticipirao središnje mjesto koje će televizor zauzeti u domovima i upotrebu tog najrazvijenijega komunikacijskog medija kao instrumenta indoktrinacije i društvene kontrole. Osim sličnosti fikcijskih svjetova iz Orwellove 1984. i Huxleyjeva Vrlog novog svijeta s današnjim društvom, rad tematizira potrošnju kao način življenja u modernom društvu i utjecaj masovnih medija na razvoj potrošačkoga mentaliteta. Ono što slijedi zapravo je verifikacija temeljne hipoteze rada da su masovni mediii kreatori utopijske i magične zbilje koju nastoje povezati sa stvarima-robama kako bi osnažile kapitalizam i potrošačko društvo.

Ključne riječi: mediii, potrošnja, tehnologija, suvremeno društvo, tehnološki napredak

Mauro Dujmović, Sveučilište Juria Dobrile u Puli, Preradovićeva 1/l, 52100 Pula, Hrvatska.

E-mail: mdujmov@efpu.hr

\section{UVOD}

Glavno obilježje književnosti na engleskom jeziku u prvoj polovici dvadesetog stoljeća bila su djela modernista. Pisci kao što su Joseph Conrad, James Joyce i Virginia Woolf revolucionirali su engleski roman. Razaranjem fabule, koja često prati tok svijesti, iščezavanjem pripovjedača, usmjeravanjem po- 
DRUŠ. ISTRAŽ. ZAGREB GOD. 20 (2011) BR. $2(112)$

STR. $541-560$

DUJMOVIĆ, M.: VRTLOG NOVOGA... zornosti na psihološki život svojih junaka i njihovih unutrašnjih monologa, sklonošću prema fragmentu i nihilističkim odnosom prema tradiciji postupno dolazi do razvoja nove književne tehnike, tj. romana toka svijesti. Međutim, 1930-ih godina javlja se novi naraštaj engleskih pisaca - Graham Greene, Evelyn Waugh i George Orwell - koji ne nastavljaju modernističku tradiciju, nego se potpuno okreću domaćoj književnosti. U djelima ove nove generacije pisaca tradicionalna fabula zauzima ono mjesto koje je imala i kod pisaca devetnaestoga stoljeća, oni nisu toliko zaokupljeni psihološkom analizom karaktera i poniranjem u svijest ili podsvijest junaka svojih romana. U takvu je ozračju nastao i književni opus Georga Orwella i Aldousa Huxleyja.

Aldous Huxley i George Orwell dva su najistaknutija romanopisca distopijske fikcije, koji su izabrali žanr znanstvene fantastike kako bi izrazili svoje neodobravanje i neslaganje s tadašnjim društvom. Znanstvena je fantastika preveliko i raznorodno područje, previše ograničeno u svojim vidovima i nekako čini se nerazborit i neprikladan izbor za odražavanje i prenošenje ciljeva antiutopije. Međutim, Huxleyjev Vrli novi svijet i Orwellova 1984. namjerno su se poslužili žanrom znanstvene fantastike kako bi zadobili pažnju širega čitateljstva. Znanstvena se fantastika kao umjetnički žanr i oblik spekulativne fikcije bavi razmatranjem utjecaja napretka znanosti i tehnologije na društvo i osobe predviđanjem razvoja čovječanstva ili pak govori o otkrivanju i zamišljanju novih pojava i tehnologija. Upravo je zato logičan izbor bio znanstveno-fantastični žanr, jer je pisanje u žanru način komunikacije između pisca i čitatelja. On zapravo govori čitatelju imena i zakonitosti svoga koda, pravila koja utječu ne samo na način pisanja nekoga djela nego i na to kako to djelo treba čitati. Da je 1984. koncipirana kao upozorenje, jasno je naglasio i sam autor: "Ne vjerujem da će do društva koje ja opisujem zasigurno doći, ali vjerujem da će doći do nečega tome nalik. Radnja romana odvija se u Velikoj Britaniji kako bi se naglasilo da rasa koja govori engleskim jezikom nije ništa bolja od bilo koje druge rase i da bi totalitarizam mogao svugdje zavladati ako se ne budemo borili protiv njega." (Orwell, 1968., vol. 4, str. 564)

Orwell i Huxley mrzili su moderno društvo sa svim njegovim tehnološkim dostignućima i čeznuli za staromodnim, prošlim, nekomercijalnim kulturama. Autori su se koristili političkom satirom kao sredstvom izražavanja prezira prema svim oblicima autokratske vlasti, sve veće i sveobuhvatne birokratizacije društva. U tom su smislu oni bili reakcionari, ali reakcionari koji su željeli zaštititi društvo od indoktrinacije, represije, tiranije i konformizma, itekako prisutnih i u današnjem društvu. Laž je za njih bila najteži zločin i na nju nisu mogli 
DRUŠ. ISTRAŽ. ZAGREB GOD. 20 (2011), BR. $2(112)$

STR. $541-560$

DUJMOVIĆ, M VRTLOG NOVOGA... pristati ni pod kojim uvjetima (Meyers, 1975.). Osnovna karakteristika Orwellova i Huxleyjeva glavnoga junaka jest potpuna nemoć, dok, s druge strane, njegov neprijatelj raspolaže apsolutnom, neograničenom vlašću. Nikakav otpor nije moguć, čak ni u mislima. Individualizam je zločin, mišljenje je zločin, pravda je nepostojeći koncept, ljubav je zločin. U tim okrutnim knjigama nema životnih radosti, glavni su heroji bespomoćni, a krajnji ishod beznadan. Međutim, usprkos svim tim karakteristikama i pojedinim kritičarima koji su pokušavali diskreditirati 1984. i Vrli novi svijet kao bezvrijedne političke horore, Orwellov i Huxleyjev roman nalaze se među najčitanijim knjigama u novijoj književnoj povijesti, gotovo su klasici našega vremena, knjige koje su u mnogim zemljama sastavni dio školske lektire.

Vrli novi svijet i 1984. imaju mnogo zajedničkih točaka, a njihova je aktualnost zapanjujuća. Ta su djela začinjena vrhunskom i vjerodostojnom imaginacijom, koja im je priskrbila važno mjesto u povijesti engleske književnosti i modernoga društva uopće. Orwellova vizija brutalne i totalitarne države 1984. dala je Velikoga Brata, misaoni zločin, novogovor, rupe u sjećanju, palaču za mučenje po imenu Ministarstvo ljubavi i obeshrabrujući prizor čizme koja će zauvijek gaziti ljudsko lice. Vrli novi svijet Aldousa Huxleyja ponudio je drugačiji, nježniji, oblik totalitarizma - konformizam postignut napretkom. Huxleyjeva vizija uključuje djecu iz epruvete, programiranje hipnozom, neograničenu potrošnju, zakonski nametnut promiskuitet, unaprijed određeni sustav kasta s kojim su svi zadovoljni i somu, drogu koja daruje instant-sreću bez posljedica.

Od 1948. godine, kada je 1984. napisana, i 1932., kada je napisan Vrli novi svijet, tehnološki napredak opisan u romanima, koji je za ono vrijeme bio čista znanstvena fantastika, danas je postao stvarnost. Njihova aktualnost dolazi posebno do izražaja danas, kada se kultura, politika i ekonomija u mediju tehnike spajaju u sveprisutan sustav koji proždire i uništava sve druge mogućnosti. Ovdje je riječ o jednom segmentu tehnologije, tj. o moćnim medijskim industrijama. Radi se o problemu koji određuje strukturu svekolikoga suvremenog svijeta. Razlog za brigu krije se u praksi moćnih, planetarno sveprisutnih masovnih medija. Ovaj rad nadahnut je dosezima kulturnih studija kao teorijsko-epistemološkoga pristupa i akademske discipline koja se već od ranih 1960-ih godina utemeljila na modelu povezivanja do tada međusobno poprilično odvojenih disciplina humanističkih i društvenih znanosti, poput kulturne i socijalne antropologije, filozofije, literarnih studija, strukturne lingvistike, komunikologije, političke ekonomije, studija filma, povijesti umjetnosti i sl., kao prototip onoga što danas nazivamo interdisciplinarnost ili transdis- 
DRUŠ. ISTRAŽ. ZAGREB GOD. 20 (2011), BR. 2 (1 12 )

STR. 541-560

DUJMOVIĆ, M.: VRTLOG NOVOGA.. ciplinarnost, omogućujući, semiotički rečeno, promatranje medija i njihovih učinaka u kontekstu produktivnog označavanja, kao procesa koji aktivno stvara kognitivne svjetove, a ne da samo pasivno reflektira nepromjenljivu postojeću stvarnost. Kulturni studiji prepoznaju kulturnu ekonomiju, u koju ulaze mediji, kao mjesta ideološke proizvodnje, stvarajući moćne predodžbe, opise, definicije i referentne okvire za razumijevanje svijeta.

Interdisciplinarnim pristupom i u kontekstu ovdje navedenih književnih djela rad hipotetički analizira hegemoniju masovnih medija te utjecaj i moć moderne tehnologije na oblikovanje ljudske svijesti i stvarnosti.

\section{MRAČNA VIZIJA SADAŠNJOSTI}

"Orwelijansko" je danas jednostavno postalo poštapalica za svaku stvarnu ili umišljenu naznaku da vlast uvodi mehanizme kontrole ljudi, da se jezik izobličuje u političke svrhe, da je otkriven novi uređaj koji će djelotvornije nadzirati ljudsku privatnost. Erich Fromm 1961. godine piše dalekosežan esej o uvidima koje Orwell pruža u 1984. i drži da su tri velike "negativne utopije" 20. stoljeća - Zamyatinov Mi, Huxleyjev Vrli novi svijet i Orwellova 1984. - lucidni izrazi osjećaja beznađa i bespomoćnosti modernoga čovjeka, koji, paradoksalno, zamjenjuju vjeru u ljudski razvoj i čovjekovu sposobnost da stvori pravedniji i miroljubiviji svijet (što su bili izrazi "pozitivnih utopija" 16. i 17. stoljeća, prosvjetiteljstva 18 . i socijalističke misli 19. stoljeća). U kontekstu 1984. Fromm pažljivo razmatra Orwellove uvide u povezanost militarizma s totalitarnom vlasti i u kontekstu blokovske podjele svijeta, Fromm izražava zabrinutost da bi konstantan strah od osobnog i nacionalnog uništenja mogao uništiti humanističko društvo. Pritom se javno zagovara upravo suprotno: da se vrijednosti poput slobode i demokracije jedino mogu sačuvati sve većom militarizacijom društva, što je za njega eklatantan primjer doublethinka (duplozofije) u zapadnim društvima. Ta dijelom nesvjesna tehnika istodobnoga podržavanja dvaju kontradiktornih uvjerenja i njihova prihvaćanja ima još mnogo primjena na Zapadu, tumači Fromm, poput one da se sastavnicom "slobodnoga svijeta" smatraju južnoameričke diktature, dok su god suprotstavljene Sovjetskom Savezu i Kini. Demokratsko uređenje i poštivanje ljudskih prava za to nisu uvjet (Fromm, 1961.).

Parola Orwellova Velikog Brata RAT JE MIR zaživjela je danas u složenoj interakciji pojedinca i društva u kojem živi. Čovjek više nije gospodar jednoga svijeta kojim može upravljati i koji se može shvatiti. Govori se o tome kako su milijuni ljudi ubijeni, o milijardama dolara nacionalnoga duga, o tisu- 
DRUŠ. ISTRAŽ. ZAGREB GOD. 20 (2011), BR. $2(112)$

STR. $541-560$

DUJMOVIĆ, $M$ VRTLOG NÓVOGA... svemirskim putovanjima, svemirskim satelitima, deseci tisuća ljudi rade u jednom poduzeću, stotine tisuća živi u gradovima. Dimenzije s kojima rukujemo jesu brojke i apstrakcije; one su daleko izvan granica koje dopuštaju neko konkretno iskustvo. Svijet više ne odgovara našim ljudskim dimenzijama. Znanost, kultura, politika izgubili su sve osnovne proporcije koje im daju ljudski smisao. Mi živimo u brojkama i apstrakcijama; budući da ništa nije konkretno, ništa nije ni stvarno. Sve je moguće, praktički i moralno. Čovjek je izbačen s određenoga mjesta s kojeg bi mogao nadgledati i upravljati svojim životom i životom društva. Njega sve brže gone snage koje je prvotno on stvorio. U takvu je svijetu on zauzet apstrakcijama i sve je udaljeniji od konkretnoga života.

Iz krila kulturnih studija tim se raspravama pridružio i poznati medijski teoretičar, predavač filozofije na kalifornijskom sveučilištu u Los Angelesu, Douglas Kellner, iako ne da bi, poput mnogih, proglasio Orwella nedosljednim socijalistom ili čak protuljevičarskim doušnikom, nego da bi njegovo viđenje i kritiku totalitarnih društava usporedio s onima Herberta Marcusea, upozorivši ipak na to da političke mislioce valja čitati povijesno i kontekstualno. U 1984. Orwell je, ustvrdit će Kellner, precizno predvidio središnje mjesto koje će televizor zauzeti u domovima i upotrebu toga najrazvijenijega komunikacijskog medija kao instrumenta indoktrinacije i društvene kontrole. Kellner Orwellu zamjera određeni konzervativizam, koji se ogleda u poticanju čežnje za onim što je bilo umjesto vizije boljega i drugačijega života u budućnosti. On nadalje smatra kako masovni mediji u suvremenom kapitalističkom društvu funkcioniraju na profinjeniji i zamršeniji način nego kruta propagandna mašina iz Orwellova romana. Po mišljenju Douglasa Kellnera, Huxley je u svojoj viziji ugodno manipulativnoga društva mnogo bliži suvremenom pojmu i funkcioniranju masovnih medija (Kellner, 1990.).

Huxleyjev roman može se čitati kao projekcija totalističkih opasnosti svojstvenih korporacijskoj državi, jednako se tako može shvatiti i kao satira američkoga života. Vrli novi svijet može se protumačiti i kao Huxleyjevo iskrivljeno i očajem potkrijepljeno znanstveno predviđanje. Huxley savjetuje čitateljima kako je svako znanstveno otkriće potencijalno subverzivno i da se ponekad čak i sa znanosti mora postupati kao s mogućim neprijateljem. "Svako otkriće u čistoj znanosti potencijalno je rušilačko; čak i znanost ponekad treba promatrati kao mogućeg neprijatelja. Da, čak i znanost" (Huxley, 1998., str. 243). Znanost i tehnologija trebaju služiti čovjeku, a ne vladati njime. Danas je moderna tehnologija uvelike uznapredovala, a Huxley i Orwell to su predvidjeli na različite načine. U predgovoru svojem izdanju iz 1946. godine Huxley je napisao 
DRUŠ. ISTRAŽ. ZAGREB GOD. 20 (2011) BR. 2 (112)

STR. $541-560$

DUJMOVIĆ, M.: VRTLOG NOVOGA... kako je Vrli novi svijet knjiga o budućnosti i, bez obzira na njezine umjetničke i filozofijske vrijednosti, može nas zanimati samo ako njezina proročanstva izgledaju ostvariva. Ljudi koji upravljaju Vrlim novim svijetom možda nisu pri zdravoj pameti (u doslovnom smislu te riječi), no nisu ni ludi, pa njihov cilj nije anarhija nego društvena stabilnost. Da bi postigli stabilnost, oni provode znanstvenim sredstvima krajnju, osobnu, istinski pokretačku revoluciju. Vjerojatno će sve svjetske države biti manje ili više totalitarne. Naravno, ne postoji razlog zbog kojeg bi novi totalitarizam nalikovao starom. Stvarno djelotvorna totalitarna država bila bi ona u kojoj svemoćna izvršna vlast političkih glavešina i njihove vojske upravljača kontrolira populaciju robova koju ne treba prisiljavati, jer ona voli svoje robovanje. U današnjim totalitarnim državama zadaća da robovi zavole svoje robovanje dodijeljena je ministarstvima promidžbe, masmedijima i učiteljima. Najveći promotivni uspjesi nisu postignuti naporima da se nešto čini, već sprečavanjem nečega da se ne učini. Istina je predivna, no još je ljepša, gledano s praktične strane, šutnja o istini. Ljubav prema robovanju nikako ne može nastati bez ekonomske sigurnosti i Huxley je vjerovao da će svemoćna izvršna vlast i njezini rukovoditelji uspjeti riješiti problem te stalne sigurnosti. Zajedno sa slobodom sanjarenja pod utjecajem droge, filmova ili radija, to će diktatorovim podanicima donijeti pomirenje s robovanjem, koje je i njihova sudbina (Huxley, 1998.).

Opasnosti Velikoga Brata i Henryja Forda danas više nisu samo literatura. One su prema sadašnjem stupnju tehnološkoga razvoja sasvim realne - prijetnja su ljudskoj slobodi i čovječnosti i skrivene su u suvremenom načinu života te se najčešće zanemaruju i ignoriraju. Zbog toga je potrebno Orwella i Huxleyja danas čitati na drugi način i iz druge perspektive, a između ostalog i zbog toga što su totalitarni režimi, u punom smislu te riječi, danas stvarno stvar prošlosti. Prijetnju više ne predstavlja partijska elita, nego progresivno potkopavanje demokracije diktaturom tihih sila koje su prirođene našem društvu. Romani 1984. i Vrli novi svijet ne znače mogućnost povratka barbarizmu nego mogućnost izopačivanja razvoja, koji je nadišao čovjekovu mjeru i njegove potrebe te je sam sebi postao svrhom (Howe, 1983.).

Totalitarizam kao pojava u današnjem društvu, ako uopće do njega dođe, neće stupiti na snagu nekim iznenadnim prevratom ili nekom kataklizmičkom promjenom, kao što je to bilo u prošlosti, nego samo suptilnim gomilanjem i postupnom erozijom tradicionalnih građanskih sloboda. Živimo $u$ društvu koje je poput Oceanije ili Svjetske Države lišeno gotovo svih moralnih i etičkih predrasuda i društvu koje tu negativnu karakteristiku tretira kao napredak. Tu prazninu popu- 
njavaju mediji i kulturna industrija kao primarni promicatelji i kreatori pojedinačnog i skupnog identiteta te stanja svijesti (Chomsky, 2002.a).

\section{NOVI TOTALITARIZAM}

Tehnološki napredak doveo je do usavršavanja postojećih i stvaranja novih medija, koji dovode ljudsku komunikaciju na novu razinu. Ali napredak i usavršavanje ne moraju nužno voditi i povećanju kvalitete čovjekova života. Orwell i Huxley opisuju tehnologiju koja služi uspostavljanju novih, učinkovitijih i ugodnijih formi društvene kontrole i širi se na manje razvijena područja svijeta (Landripet, 2004.). Zahvaljujući golemim poboljšanjima u komunikaciji i načinima transporta, globalni pokret ljudi, kao i materijalnih i simboličkih dobara, stalno raste. Vijest se širi vrlo brzo i trenutačna je. Sredstva masovne komunikacije i dalje se ubrzano razvijaju. Mediji su nezaobilazni i svakodnevni dio života mnogih ljudi. Oni odražavaju i stvaraju socijalni i kulturni svijet u kojem ljudi žive (Eco, 1996.).

Francuski istraživač Philippe Breton (2005.) smatra da u ljudskoj povijesti nema ništa slično načinu na koji se u suvremenom svijetu učvrstila medijska moć, medijski nazovi-monopol nad kruženjem informacija. Predodžba o čovjeku kao biću koje je potpuno posvećeno komunikaciji i podvrgnuto tiraniji slike (i svoje i onih koje mu donose mediji) postala je dominantna. Činjenica da su svu svoju moć usredotočili na informaciju pretvara medije u potencijalno oruđe za opsežne dezinformacijske pothvate.

Nekomercijalni sadržaji praktički su nestali iz medija u korist lake zabave. Mediji iskorjenjuju kritički duh iz javnoga života, nudeći teledirigiranje, spektakularno nadmetanje i malo propagande, a ponajviše nižerazrednih spektakala za mase (Katunarić, 2005.).

Mediji vladaju svijetom. Ali ne dolazi otuda totalitarizam medija. Nisu to jedne te iste emisije koje cirkuliraju na tisućama kanala, nije to isto smeće što kruži svemirom. Mediji uništavaju ljudsku misao. Dosad je misao bila progonjena, diktatori i režimi su je progonili, htjeli joj doći glave, ali ona je bila negdje skrivena ili ilegalna i čekala da led pukne i da izbije na površinu. Ako je totalitarizam provodio cenzuru, sada je na djelu sensura ili otimanje smisla. Riječ je o praznini ispunjenoj slikama koja nastupa umjesto misli i daje dojam punoće i prelijevanja vizualnih sadržaja u mentalni prostor, tako da se on posve zauzme i istisne aktivnost mišljenja. Taj proces doseže maksimalno savršenstvo jer se provodi bez i najmanjeg otpora i prisile. Ono djeluje u kombinaciji s demokratskom cenzurom, gdje preobilje ili zasićenje kontaminiranim informacijama proizvodi udaljavanje od bitnoga. Čovjek se degradirao na 
DRUŠ. ISTRAŽ. ZAGREB GOD. 20 (2011) BR. $2(112)$

STR. $541-560$

DUJMOVIĆ, M.: VRTLOG NOVOGA... ulogu manekena. Očaran je bezvrijednošću, jeftinoćom, šupljikavošću, tričavošću. Pojaviti se u medijima znači postojati i biti živ (Vidović, 2006.).

Medijski kritičar i komunikolog Neil Postman još je sredinom 1980-ih godina u knjizi Amusing Ourselves to Death (1986.) upozorio na tu prevladavajuću ideologiju medija zasnovanu na ugodi i zabavi. Ona je, prema njegovu mišljenju, samo jedan od mogućih oblika društvene kontrole nad pojedincima, onako kako je to u Vrlom novom svijetu već upozorio Aldous Huxley. Postman definira moderno društvo kao tehnopolis, tj. društvo kojim dominira i upravlja moderna tehnologija. To je napredak bez granica koji karakterizira proizvodnja velike količine informacija bez mehanizama za njihovo vrednovanje. Tehnopolis je kulturno stanje i stanje duha, koje se sastoji od deifikacije tehnologije, što znači da kultura traži svoju autorizaciju, satisfakciju i poredak u tehnologiji.

Ugoda koju televizija promovira kao vrhunsko načelo, naime, može uništiti društvo, jer degradira i obezvrjeđuje ozbiljan javni diskurs. Također, prikazivanje nasilja na zabavan način degradira mnoge ljudske moralne i društvene zakone $\mathrm{i}$ pravila, ali i obezvrjeđuje sam život (Longhurst i sur., 2008.). Dok je industrijsku eru obilježila komodifikacija rada, u doba pristupa radi se, prije svega, o komodifikaciji igre. Kulturni rituali, društvena događanja i okupljanja, umjetnosti, sportovi i igre, društveni i građanski pokreti - sve je to uključeno u komercijalnu sferu. Kulturna proizvodnja predstavlja posljednji stadij kapitalističkoga načina života, čija je glavna misija uvijek bila dovesti što više ljudskih aktivnosti u komercijalnu arenu.

Kapitalističko putovanje, koje je započelo komodificiranjem prostora i materijalnoga, završava se komodifikacijom ljudskoga vremena i trajanja. Prodavanje kulture, u obliku sve većeg broja ljudskih aktivnosti za koje se plaća, ubrzano vodi u svijet $\mathrm{u}$ kojem novčani međuljudski odnosi postaju supstitucija za tradicionalne društvene odnose. Život se sve više i više komodificira, a komunikacija, općenje i tržište postaju nerazlučivi (Rifkin, 2005.).

Orwellova i Huxleyjeva knjiga danas nam mogu poslužiti kao upozorenje da shvatimo kako daljnji napredak i približavanje savršenoj tehnologiji znači i tehnokraciju proizvodnoga i potrošačkoga svijeta, prožetog potpunom kompjuterskom kontrolom. Baš kao što su tiskani mediji u proteklih nekoliko stotina godina promijenili ljudsku svijest, računala bi u sljedećih nekoliko stoljeća mogla imati sličan učinak na svijest. Dok se petina svjetske populacije seli u kibernetički prostor (cyberspace) i u odnose pristupa, ostatak čovječanstva još je čvrsto u šakama materijalne oskudice. Za siromašne život je i 
DRUŠ. ISTRAŽ. ZAGREB GOD. 20 (2011), BR. 2 (112)

STR. $541-560$

DUJMOVIĆ, M VRTLOG NOVOGA... dalje dnevna bitka za opstanak, a imovina im je glavna preokupacija - i za mnoge od njih samo daleki cilj. Njihov je svijet vrlo daleko od optičkih kabela, satelitskih veza, mobitela, zaslona računala i interneta. Jaz između onih koji posjeduju i onih koji ne posjeduju golem je, no jaz između umreženih i neumreženih još je veći. Svijet se ubrzano dijeli na dvije razdvojene civilizacije - na one koji žive unutar elektroničkih vrata kibernetičkoga prostora i na one koji ostaju vani. Upravo stoga što su tako sveobuhvatne, nove globalne digitalne komunikacijske mreže rezultiraju stvaranjem novoga, totalitarizirajućeg društvenog prostora, druge zemaljske sfere na majci Zemlji, sfere koja obitava u eteru kibernetičkoga prostora. Pojam pristupa i mreža postaje sve važniji i počinje redefinirati društvenu dinamiku postmodernoga doba tako snažno kao što je to činila ideja vlasništva i tržišta u osvit modernoga doba (Rifkin, 2005.).

Novi komunikacijski sustavi često su predstavljeni kao ključ koji otvara vrata boljega života i pravednijega društva. Diskurs koji okružuje nove komunikacijske sustave uglavnom obraća pažnju na predstojeće tehničko povećanje u razmjeni informacija i načine na koje će se ta prednost odraziti na pojedince i institucije. Orwell i Huxley u svojim su romanima predvidjeli dolazak ovoga važnog fenomena. Kapitalističko putovanje koje je započelo komodificiranjem prostora i materijalnog završava se komodifikacijom ljudskoga vremena i trajanja. Kultura se prodaje u obliku sve većega broja ljudskih aktivnosti. Život se sve više i više komodificira, a komunikacija, općenje i tržište postaju nerazlučivi.

\section{HEGEMONIJA POTROŠAČKE KULTURE}

Orwellova 1984. izraz je stanja i raspoloženja. To nije uprizorenje budućnosti, nego upozorenje da se takvo što ne dogodi. Izrazit očaj, krajnji pesimizam i besperspektivnost čovjekove sadašnjosti i budućnosti glavne su odlike ovoga romana, a upozorenje se odnosi na činjenicu da ako se u tijeku povijesti i razvoja ljudskoga društva nešto ne promijeni, ljudi će širom svijeta izgubiti većinu svojih ljudskih obilježja i postati automati bez duše, a da toga neće biti ni svjesni (Burgess, 1978.).

Ta slika beznađa ljudske budućnosti u pukoj je suprotnosti s jednim od temeljnih obilježja suvremene humanističke misli, a to je vjera u ljudski napredak i čovjekovu sposobnost izgradnje pravednoga i mirnodopskoga svijeta. Orwell nije osamljen u ovom svom razmišljanju. Aldous Huxley je u svojem romanu Vrli novi svijet izrazio slična stajališta o sadašnjosti i upozorio na moguće negativne aspekte nadolazećega svijeta budućnosti. Ove dvije negativne utopije, ili bolje rečeno distopije, napisane sredinom 20. stoljeća prožete su osjećaji- 
DRUŠ. ISTRAŽ. ZAGREB GOD. 20 (2011) BR. 2 (112)

STR. $541-560$

DUJMOVIĆ, M.: VRTLOG NOVOGA... ma čovjekove bespomoći i beznađa, baš kao što su rana utopijska djela širila vjeru ondašnjega čovjeka u samopouzdanje i nadu za boljim i pravednijim društvom. U povijesnim okvirima ne postoji veći paradoks od ove promjene. $S$ jedne strane imamo čovjeka na početku industrijskoga doba, kada i nije posjedovao sredstva za zadovoljenje svih svojih potreba i kada je živio u svijetu rata, ropstva i eksploatacije, u svijetu u kojem je vjera $\mathrm{u}$ znanost i njezina primjena na polju tehnoloških dostignuća i proizvodnje na početku modernog razvoja predstavljala nadu u bolje sutra. $S$ druge strane, taj isti čovjek četiri stotine godina kasnije, kada je u situaciji da konačno posjeduje sva potrebna sredstva za ostvarenje svih svojih nadanja i kada proizvodi i više nego što mu je potrebno, $u$ svijetu u kojem nema potrebe za ratovanjem, jer tehnološki razvoj može pružiti više bogatstava od teritorijalnih osvajanja, u svijetu ujedinjenom globalizacijom, kada je čovjek na pragu ostvarenja svih svojih stremljenja, on počinje gubiti nadu. To je zapravo bit ovih distopija, dakle ne samo da opišu budućnost koja dolazi nego i da objasne ovaj povijesni paradoks (Atwood, 2007.).

Iako su opasnosti od totalitarizma kakav opisuje Orwell danas stvar prošlosti, njegov je roman korisna kritika kapitalističkoga potrošačkog društva, i to u onoj mjeri u kojoj prikazuje kontrolu kapitala nad političkom, socijalnom i kulturnom sferom društva i sintezu kapitala i tehnologije kao novog oblika društvene kontrole i dominacije. U 1984. politička represija, mučenja i ubojstva instrumenti su društvene kontrole i manipulacije. Vrli novi svijet nije tako okrutan i promovira hedonizam, a društvenu kontrolu instrumentalizira dominantnom kulturom, konzumerizmom i manipulacijom masama, čija je funkcija integracija pojedinca u društvo i proizvodnja onoga što Marcuse naziva jednodimenzionalnim društvom i čovjekom jedne dimenzije. Huxleyjev je roman, čini se, mnogo bliži suvremenom konceptu potrošačkoga društva. Orwell je svoju kritiku ograničio uglavnom na represivni i centralizirani državni aparat i političku birokraciju. Huxley opisuje društvo u kojem kibernetika, uvjetovano ponašanje, potrošnja, masovna kultura, liberalizirano seksualno ponašanje i sustavna kontrola misli i ponašanja proizvode uvjetovanoga pojedinca, sretnog što obnaša ulogu koju mu je društvo namijenilo. Država ovdje ima ulogu administriranja toga znanstveno-kibernetičkog sustava kojim upravljaju disciplina, racionalnost i efikasnost, a ne žudnja za moći i užitkom koja proizlazi iz sadističke dominacije odabrane manjine nad preostalom većinom. Većina kapitalističkih i socijalističkih društava današnjice služe se mješavinom metoda uvjeravanja i prisile, sile i hegemonije, tako da je Orwellovo isticanje i inzistiranje na moći 
DRUŠ. ISTRAŽ. ZAGREB GOD. 20 (2011), BR. 2 (112)

STR. $541-560$

DUJMOVIĆ, $M$ VRTLOG NOVOGA... i državnom teroru trebalo dopuniti Huxleyjevim inzistiranjem na manipulaciji i novim oblicima društvene kontrole.

Moć je praksa, ritual, proces, kojim neki ljudi rukuju više nego drugi. Nejednako je raspoređena i nejednako nametnuta. Moć se iskazuje na niz načina - od izravne prisile preko privrženosti standardima zajednice. Na jednom su kraju osoblje i tehnika države prisile i korporativnog aparata, a na drugom društvene norme koje definiraju što je ispravno. Huxley opisuje mjesto na kojemu se red održava seksualnim promiskuitetom i lakom dostupnošću droga. Orwellov je svijet puritanski, grub i opor. Moć je u modernom kapitalističkom društvu raspršena u razne institucije, discipline i diskurse i primjenjuje širok spektar programa socijalne pomoći, agencija, školovanja i tehnika, poput psihoterapije, zatvora i medija $\mathrm{u}$ svrhu socijalizacije pojedinca i potiskivanja devijacije (Chomsky, 2002.b).

Umjesto čizme koja zauvijek gnječi ljudsko lice, u kapitalističkom potrošačkom društvu devijantno ponašanje liječi se tehnikama kontrole ponašanja. Čini se da kapitalističko društvo nema potrebe nadzirati svaki aspekt života i da je u svojoj primjeni društvene kontrole sklonije pribjeći instrumentalizaciji medija i popularne kulture. Koncepti istine i stvarnosti koji postoje u 1984. i Vrlom novom svijetu krajnji su oblik pragmatizma u kojem je istina podređena vladajućim klasama. Jedno od karakterističnih i najdestruktivnijih obilježja modernog društva jest da čovjek sve više postaje instrument $i$ da sve više pretvara stvarnost $u$ nešto relativno svojim vlastitim interesima i funkcijama. Odnos između države Oceanije i njezinih građana jest odnos između moći i njezinih žrtava i ne može se nazvati humanim. Moći treba dati ljudski oblik (Veliki Brat na posterima), ali to je samo zato da bi žrtve mogle tu moć identificirati i neminovno joj se pokoriti. To pokoravanje mora biti dobrovoljno, a duplozofija je instrument koji udobrovoljava žrtve. Ako je pojedinac potpuno predao svoju neovisnost i integritet i ako osjeća da pripada državi, partiji ili u naše vrijeme korporaciji, onda je dva plus dva jednako pet i sloboda je ropstvo i osjeća se slobodno jer ne postoji više protuslovlje između istine i laži. Duplozofija je moć uspješne manipulacije razumom i pojedinac više ne govori suprotno od onoga što misli, nego misli suprotno od onoga što je istinito. Svojedobno je Erich Fromm napisao: "Čitalac će u Orwellovu opisu 1984. pronaći mnoge karakteristike našega današnjeg društva - pod uvjetom da prevlada vlastito dvomišljenje" (Fromm, 1980.).

Kontrola misli je u kapitalističkom društvu mnogo ugodnija, sveprisutna i višeslojna, za razliku od grube i beskonačne propagande kojoj su izloženi stanovnici 1984. U 1984. tele- 
DRUŠ. ISTRAŽ. ZAGREB GOD. 20 (2011) BR. 2 (112)

STR. $541-560$

DUJMOVIĆ, M.: VRTLOG NOVOGA... vizija (teleekran) uvijek je upaljena i ne može se ugasiti (to je povlastica povlaštenih) te ima samo jedan program. Mediji teroriziraju, nadgledaju i indoktriniraju građane i njihova je primarna zadaća indoktrinacija i zastrašivanje građana, konstantno ih podsjećajući na sveprisutnost i apsolutnu moć partije. U 1984. televiziju posjeduju svi građani i ona ih svako jutro budi, prisiljava ih da izvode vježbe i izvikuju slogane za vrijeme Dvominutne mržnje i uskraćuje im privatnost izjednačujući pojedinca s masom. Za razliku od ovoga modela, suvremeni masovni mediji funkcioniraju na potpuno drukčiji način. Oni strukturalno privatiziraju i depolitiziraju pojedince, zadržavajući ih u sigurnom okruženju vlastita doma i u izolaciji od neke javne ili društvene aktivnosti. Sam čin gledanja televizije privatizira pojedince i često sublimirajuće nameće slike, uzore i vrijednosti koje oblikuju svijest i ponašanje pojedinca, odvraćajući mu pozornost od društvenih i političkih pitanja i problema. Većina gledatelja nije ni svjesna da gledanje televizije, zabavnih programa, vijesti ili oglašavanja indoktrinira pojedinca i nameće mu dominantne vrijednosti, vjerovanja, stavove i oblike ponašanja (Eco, 2005.).

Društva 1984. i Vrlog novog svijeta prikazana su kao izrazito tehnokratska društva. Tehnološki napredak opisan u romanima u vrijeme njihova nastanka bio je čista znanstvena fantastika, a danas je postao stvarnost. Tehnologija jasno i nedvojbeno utječe na svakodnevno formiranje prirode potrošačkoga društva. Čini se da živimo u tehnološkom društvu u kojem smo kao potrošači prisiljeni na pasivnu potrošnju. Tehnologija nas zavodi iluzijom interaktivnosti i liberalizacije, promovirajući pritom pasivnost potrošača i vodeći se zakonima tržišta, pri čemu je potrošač samo gubitnik. Znanost i tehnologija iznevjerile su očekivanja i nisu svijetu donijele prosperitet i više slobodna vremena. Tehnologija je odvela čovjeka na mjesec, ali mu nije osigurala znatno veću količinu slobodna vremena. Danas čovjek nastoji potrošiti dostupno slobodno vrijeme na potrošnju, koja pred potrošače uvijek iznova postavlja nove izazove, promovirajući veći izbor, ali samo da bi održala konzumerizam kao dominantan životni stil (Jhally, 2004.). Na tehnologiju se sve manje gleda kao na promotora ljudskoga napretka, a sve više kao na tržište koje je važnije i od progresivne prirode same tehnologije.

Čini se da su se Orwellova i Huxleyjeva strahovanja obistinila i da tehnologija danas postaje moćnija od ljudi koji je konzumiraju. Očito je da razvoj tehnologije ima važne implikacije na potrošača. $S$ jedne je strane primjena tehnologije $u$ procesu proizvodnje u razvijenom svijetu poslužila za povećanje životnoga standarda i prosperiteta, dok je s druge ta ista tehnologija otvorila put povlaštenoj klasi ljudi za još većom 
DRUŠ. ISTRAŽ. ZAGREB GOD. 20 (2011), BR. 2 (112)

STR. $541-560$

DUJMOVIĆ, $M$ VRTLOG NOVOGA... zaradom i zgrtanjem još više svjetskoga bogatstva u vlastitu korist. Računalna revolucija najsnažnije je oružje u rukama povlaštenih, posebno u kontekstu prikupljanja i procesuiranja informacija. Ove činjenice dovoljno govore o paradoksalnoj prirodi modernoga potrošačkog kapitalističkog društva. Orwell i Huxley impliciraju da novi oblici menadžerskog industrijalizma, u kojem čovjek izrađuje strojeve koji se ponašaju poput čovjeka i razvija čovjeka koji se ponaša poput stroja, pridonose razvoju ere dehumanizacije i otuđenosti u kojoj je čovjek pretvoren u stvar i postao je dodatak procesu proizvodnje i potrošnje.

Potrošnja ima dvostruku ulogu; s jedne strane, ona je agent društvene kontrole, a s druge, aktivno stvara potrošačku kulturu. Iako se ekonomski sustav reproducira kroz potrošnju i u tom pogledu proizvod je ideološki materijal, neki teoretičari, poput Fiskea (Fiske i Hartley, 1992.), smatraju da potrošnja barem djelomično potencijalno oslobađa, i to tako što ljudima omogućuje polazišnu osnovu u borbi protiv kapitalističkih ideoloških imperativa. Ako otpor i postoji, onda je on aktiviran u kulturnoj, a ne ekonomskoj, sferi. Nisu svi potrošači lakovjerni i postoji velik broj njih koji su potpuno svjesni i kritični prema nejednakostima i nepravdama koje konzumerizam generira. Očito je da potrošački kapitalizam ne funkcionira samo na lažnoj svijesti. Moć konzumerizma leži upravo u činjenici da održanje segmentiranih tržišta zahtijeva određeni stupanj potrošačke individualnosti. U svakodnevnom, rutinskom životu čovjek nema potrebu i ne osjeća shodnim propitkivati valjanost i smisao konzumerizma kao načina života. Smisao i značenje ljudima u njihovim životima pružaju snovi koji su uronjeni $\mathrm{u}$ konzumerizam. U tom kontekstu predvidivost i sigurnost jesu stvar prošlosti, a život obilježava nesigurnost i na mikroplanu i na makroplanu. U društvu rizika konzumerizam ima veoma važnu ulogu kao okvir unutar kojega ljudi žive svoje živote. Ironija je potpuna, pa iako ljudi žive u sve individualiziranijoj kulturi, pojedinac ne egzistira autonomno. Njegova individualnost podložna je vanjskim utjecajima i silama, a posebice standardizaciji, koja u njemu izaziva sklonost osobnim krizama. U suvremenom društvu sve to vodi intelektualnom robovanju, omalovažavanju osobne poduzetnosti, srozavanju moralne razine ljudi i kočenju napretka. Danas je individualizam - navodno sredstvo postizanja punog razvoja vlastita bića - samo obmana i pojedinac je potpuno ovisan o silama standardizacije i diverzifikacije potrošačkoga kapitalizma.

Kultura potrošnje ne bi se mogla širiti bez tehnološke osnovice, a nju čine mediji. U medijskim je studijima već odavno odbačena teza o medijima kao ogledalu društva i medij- 
DRUŠ. ISTRAŽ. ZAGREB GOD. 20 (2011) BR. $2(112)$

STR. $541-560$

DUJMOVIĆ, M.: VRTLOG NOVOGA... skoj realnosti koja je tek posrednik socijalne, političke, kulturne, ekonomske i svake druge zbilje, dakle odvojena od te složene društvene strukture, funkcionirajući kao njezin promatrač, izvjestitelj i arhivar. Veoma je teško odrediti granicu između medijske i društvene realnosti. Medijska realnost nije ništa drugo nego dio šire društvene realnosti, jedan od njezinih važnih segmenata koji izravno i aktivno sudjeluje u stvaranju neposredne životne zbilje. Teorije koje svoj konceptualni fond grade na tradiciji strukturalne lingvistike, semiotike, teorijskoj psihoanalizi, strukturnoj antropologiji i brojnim učenjima postmodernizma promatraju stvarnost kao proces stvaranja značenja u zavisnosti od političkih, socijalnih, kulturnih, ekonomskih, medijskih i brojnih drugih čimbenika. Sfera javnosti postala je roba koja se može kupiti i prodati. Spektakl, hiper-stvarnost, preoblikovanje sfere javnoga u potrošnu robu samo su neki od naziva za prevlast masovnih medija u suvremenom društvu. Konačni rezultat kapitalističke slobodnotržišne organizacije masovnih medija jest stvaranje koncentriranih i centraliziranih medijskih konglomerata sa sve užim i užim interesima. Koncentracija monopola na taj način vodi $\mathrm{k}$ monopoliziranoj i koncentriranoj vlasti nad medijima, koja, pak, potiče sve izravniji i sveobuhvatniji korporacijski nadzor nad popularnom kulturom i društvom. Roba postaje znakom, a potrošnja trošenjem znakova, ona je semiotički sustav koji prethodi pojedincu i preko kojeg se ljudi povezuju s društvenim poretkom. Uporabna vrijednost roba zamijenjena je modelima, kodovima, simulakrumima i spektaklima, a potrošnja prerasta u univerzum komunikacije (Baudrillard, 2005.).

Potrošnja i masovni mediji potiskuju čovjekovu individualnost i odvraćaju ga od njegove duševne potrebe za svrsishodnim djelovanjem. Čovjek koji ne pronalazi mogućnost kreativnog izražavanja žudi za ispunjenim i autentičnim životom. Mediji sugeriraju da takav oblik života dolazi s proizvodima ili zapakiranim komercijalnim iskustvima. On ne proizvodi zbog konkretnoga zadovoljenja, već u apstraktnu svrhu prodaje robe; osjeća da kupovanjem može doći do svega materijalnog i nematerijalnog i tako prisvaja stvari bez ikakva osobnoga stvaralačkog napora. Naglasak tako prelazi sa zadovoljenja stvaralačke aktivnosti na vrijednost gotovoga proizvoda. Time čovjek propušta jedino zadovoljenje koje mu može pružiti stvarnu sreću - doživljaj aktivnosti u danom trenutku - pa juri za varljivom srećom koja se naziva ispunjenjem (Marcuse, 1989.).

Masovni mediji i popularna kultura osiguravaju kontekst unutar kojeg cirkulira potrošnja i centralno su mjesto stvaranja masovnoga pojedinca. Konzumerizam svakako treba proma- 
trati kao nužnu snagu u reprodukciji kapitalizma i održavanju kapitalističke hegemonije i kolonizacije kulture.

\section{ZAKLJUČAK}

U promišljanju svih pojava u suvremenom društvu, o kojima je bilo riječi u ovom radu, a u kontekstu 1984. i Vrlog novog svijeta, ključna je upravo njihova kulturna ili kulturološka komponenta. Najveća vrijednost ovih djela leži u činjenici da su njihovi autori svojim pisanjem predvidjeli i nagovijestili dolazak korjenitih promjena $\mathrm{u}$ obrascima društvenih odnosa, posebno kulture i ekonomije, te naznačili prijelaz na novu kulturnu paradigmu nazvanu postmodernizam, kao izraz zreloga kapitalizma i suvremenih tehnoloških dostignuća (Brooker, 1992.). Iako među teoretičarima popularne kulture, poput Baudrillarda, Foucalta, Lyotarda itd., ne postoji jedinstveno stajalište, postmodernizam se shvaća kao promjena načina na koji se vidi svijet i načina prezentiranja povijesti, sadašnjosti i budućnosti. Svijet je doživio osjetne strukturne promjene u ekonomiji, tako da su deindustrijalizacija, postfordizam, fleksibilizacija rada, dominacija potrošnje i proizvodne veze ustupile mjesto znakovima i simbolima.

Postmodernu kao povijesno razdoblje, za razliku od moderne, karakterizira odmak od društva koje se temelji na proizvodnji prema društvu koje se temelji na potrošnji i razmjeni informacija i važnosti koju mediji i nove komunikacijske i informatičke tehnologije imaju u njihovu širenju. Virtualni prostor danas je polazna tehnološka platforma za inovacije u domeni novih uređaja, novih kultura, novih poslova, novih tržišta, novih bogatstava i novih izvora moći u društvu. Nove su tehnologije razvojem medija i razvojem novih komunikacijskih mogućnosti potaknule jaku diverzifikaciju kulturnoga stvaralaštva i kulturnih vrijednosti. Danas su mediji glavni pokretači kulturnog kapitalizma, faze razvoja kapitala u kojoj je izvor zarade sve više informacijski, utemeljen na podacima, vizualniji - novine, časopisi i knjige; glazba, filmovi i računalne igre, hardver za pristup raznim medijima, koji kulturnu robu čuvaju i prodaju. Postmoderna kultura je kultura u kojoj prevladavaju medijske slike i u kojoj su ljudi okrenuti drugim mjestima i vremenima uz pomoć proliferirajućih informacijskih tokova. Kulturna proizvodnja postaje decentralizirana, višedimenzionalna, rascjepkana i plitka. S gotovo bezgraničnim tehnološkim mogućnostima masovne proizvodnje, reprodukcije i širenja znakova i simbola, sve je teže definirati svijet.

Kulturna ili kreativna ili tzv. nova ekonomija kao glavno obilježje postmodernizma reproducira neoliberalnu transnacionalnu prirodu suvremenoga globalnog kapitalizma. Razvija se na temelju upotrebe generičkih informacijskih i komu- 
DRUŠ. ISTRAŽ. ZAGREB GOD. 20 (2011) BR. $2(112)$

STR. $541-560$

DUJMOVIĆ, M.: VRTLOG NOVOGA... nikacijskih tehnologija, odnosno kreativnom proizvodnjom, distribucijom i potrošnjom simbola i vrijednosti. Nastaje $u$ umreženome društvu i utječe na kulturalizaciju ekonomskoga života, odnosno na shvaćanje kulture kao proizvodnoga i razvojnoga resursa. Globalna je ekonomija suvremeni orvelovski pojam. Globalizacija je rezultat kompresije vremena i prostora, što se dogodilo zbog napretka tehnologije koji je omogućio trenutačnu raspodjelu informacija diljem svijeta i svijet je postao globalno selo. Važno je pritom napomenuti kako se kultura, politika i ekonomija u mediju tehnike spajaju u sveprisutan sustav koji proždire i uništava sve mogućnosti. Kulturna se proizvodnja povezuje i spaja s proizvodnim procesima na drugim područjima, što je zasnovano na globalnom širenju generičkih tehnologija, osobito informatičke. Takva strukturalna i sistemska kulturalna tranzicija obilježena je jakim migracijama stanovništva, širenjem velikih gradova i gotovo nestajanjem nacionalnih granica, usklađivanjem globalnih trendova liberalnoga kapitalizma potrošačkih društava s kulturnom industrijalizacijom. U postindustrijskom društvu kultura, znanje i informacije postali su temeljni razvojni resursi kreativne industrije i kreativne ekonomije kao postmodernističkih izvora moći. Međutim, paralelno s time nositelji moći i globalizacije u svijetu pokušavaju na zastarjeli način transformirati svoju moć iz prošlosti, skupa sa svjetonazorom koji je hedonistički, nehumanistički i pokušavaju ga primijeniti na to tehnološki idealno globalizacijsko vrijeme. U tom kontekstu suvremeno je društvo vrlo blisko fantastičnim svjetovima 1984. i Vrlog novog svijeta. Distopijske karakteristike globalizacije uvjetuje opći imperativ uvećanja kapitala i profita kao nužnosti akumulacije ekonomske, političke i kulturne moći. Takav odnos snaga u globalnom je svijetu općenito gledano negativno razvojno dostignuće. Iako je civilizacija u shvaćanju čovjeka i društvenih grupa, nacije, pojedinaca otišla daleko, odnosi moći u društvu ostaju uvijek isti. Stara potreba za moći i stare strukture moći pokušavaju zadržati moć, s nizom negativnih posljedica. Kapital, informacija i komunikacija predstavljaju temeljni trio za promišljanje o globalizaciji, koja se u općem smislu označuje kao neoliberalna distopija planetarnoga doba. Pilger (2002.) smatra da je posljedica ovakva razvoja svijet u kojemu elita upravlja s osamdeset posto bogatstva čovječanstva. Ovakvu globalnu kulturnu ekonomiju promiču transnacionalne svjetske medijske korporacije, koje posjeduju ili upravljaju glavnim izvorima vijesti i informacija $u$ svijetu. One su preobrazile velik dio informacijskoga društva u medijsko doba u kojem profinjena tehnologija omogućuje neprestani protok eliti prihvatlivivih informacija. Globalizacija je univerzalna ideologija novoga svjetskog poretka, koju ka- 
DRUŠ. ISTRAŽ. ZAGREB GOD. 20 (2011), BR. $2(112)$

STR. $541-560$

DUJMOVIĆ, $M$ VRTLOG NOVOGA..

\section{LITERATURA}

rakterizira postmoderna potrošačka kultura promjenjiva identiteta. Dok je smisao i svrha genetskog inženjeringa u Vrlom novom svijetu i partijske opresije u 1984. očuvanje sadašnjih odnosa i postojeće ideologije, $u$ današnjem svijetu bit postmoderne kulture jest ideologijsko opravdanje globalnoga kapitalizma kao prirodno racionalnoga svjetskog sustava potreba. Ovaj dinamički proces temeljito mijenja mnoge društvene odnose: smanjuje troškove i ubrzava komunikaciju i transport robe, usluga, kapitala i znanja te stvara nove globalne institucije. Ova dinamika suvremenoga društva bitno i nedvosmisleno utječe na svakodnevnu egzistenciju velikoga broja ljudi. Svijet koji nastaje svijet je radikalne diskrepancije između bogatih i siromašnih, i to je bitna činjenica društvene strukture suvremenoga svijeta. Takva dinamika suvremenoga društva dinamika je globalizacije, i to je način na koji sada živimo.

Možda upravo u ovim činjenicama leži daljnje sagledavanje i objašnjenje povijesnoga paradoksa o kojem je bilo riječi na početku ovoga poglavlja. Gubitak nade i vjere modernoga, tj. postmodernoga, čovjeka u bolje sutra kulturni je konstrukt i posljedica širega društvenog djelovanja i utjecaja kulturne ili kreativne proizvodnje kojom je prožet čitav naš vrijednosni sustav, sve naše dnevne navike i ukupan način života. Postindustrijsko, postmoderno stanje još je pred nama; pitanja koja postavljaju postmodernistički mislioci važna su i neće samo tako nestati. Baš kao što su nekad neupitne institucije prevladavane, tako i sadašnje načine mišljenja i djelovanja treba stalno preispitivati. Distopijske projekcije budućnosti iz 1984. i Vrlog novog svijeta podsjećaju nas na to da su razumijevanje i spoznaja uvijek provizorni procesi koji zahtijevaju stalno razmatranje i koji nemaju svršetka. Imaginacija bi trebala biti oslobođena ograničenja i poslužiti čovječanstvu kao poticaj kritičkoga preispitivanja prošlosti, sadašnjosti i budućnosti. U kontekstu današnjega društva na ova književna djela treba gledati kao na provizorna predviđanja. Potraga za budućnošću, kao što je to sa svim postmodernim pojmovima, beskrajan je proces samopreispitivanja. Konačno, trebamo naučiti više o tome kako proizvodnja postmoderne kulture i njezina diseminacija utječu na život i iskustvo raznih ljudi i što ta diseminacija može značiti za budućnost.

Atwood, M. (2007.), How Does Aldous Huxley's Vision of a Totalitarian Future Stand Up 75 Years After Brave New World Was First Published, The Guardian, Saturday, November 17, http://www.guardian. co.uk/ (14. 4. 2007.)

Baudrillard, J. (2005.), Iznad istinitoga i neistinitoga. Europski glasnik, 10 (10): 189-199.

Brooker, P. (1992.), Modernism/Postmodernism, Harlow: Longman. 
DRUŠ. ISTRAŽ. ZAGREB GOD. 20 (2011) BR. 2 (112),

STR. $541-560$

DUJMOVIĆ, M.: VRTLOG NOVOGA...
Burgess, A. (1978.), 1985, London: Arrow Books.

Chomsky, N. (2002.a), Mediji, propaganda i sistem, Zagreb: Što čitaš?

Chomsky, N. (2002.b), Propaganda i javno mišljenje, Zagreb: VBZ.

Eco, U. (2005.), Zvuci i slike. Europski glasnik, 10 (10): 171-189.

Eco, U. (1996.), Od Interneta do Gutenberga, predavanje na akademiji za napredne studije u Americi, http://boo.mi2.hr/čognjen/tekst/eco96.htm (5. 4. 2008.).

Fiske, J. i Hartley, J. (1992.), Čitanje televizije, Zagreb: Barbat \& Prova. Fromm, E. (1980.), Beyond the Chains of Illusion, London: Abacus.

Fromm, E. (1961.), Afterword. U: G. Orwell, 1984 (str. 257-267), New York, Signet Books, http://www.geocities.com/c_ansata/1984.html (19. 5. 2008.).

Howe, I. (1983.), 1984 Revisited, New York: Perennial Library.

Huxley, A. (1998.), Vrli novi svijet, Zagreb: IZVORI d.o.o.

Jhally, S. (2004.), Oglašavanje, religija i magija. Libra Libera, 14: 41-48.

Katunarić, D. (2005.), Dajte jednu minutu Hitleru, jednu minutu Židovima. Bilješke o degradaciji medijske zbilje. Europski glasnik, 10 (10): 441-451.

Kellner, D. (1990.), From 1984 to One-Dimensional Man: Reflections on Orwell and Marcuse, Current Perspectives in Social Theory (str. 223-252), Greenwich, CONN. JAI Press.

Landripet, I. (2004.), Orwellova 1994. Aktualost distopijskog predloška i implikacije novootkrivenog "djela". Diskrepancija, (5) 9: 41-54.

Longhurst, B., Smith, G., Bagnall, G., Crawford, G. i Ogborn, M. (2008.), Introducing Cultural Studies, Harlow: Longman.

Marcuse, H. (1989.), Čovjek jedne dimenzije, Sarajevo: Veselin Masleša. Meyers, J. (1975.), George Orwell: The Critical Heritage, London: Routledge \& Kegan Paul.

Orwell, G. (1968.), The Collected Essays, Journalism and Letters of George Orwell, London: Penguin Books.

Orwell, G. (2001.), 1984., Zagreb: Alfa.

Pilger, J. (2002.), Novi vladari svijeta (preveo: Vladimir Cvetković), Zagreb: Epifanija.

Postman, N. (1986.), Amusing Ourselves to Death: Public Discourse in the Age of Showbusiness, London: Heinemann.

Rifkin, J. (2005.), Doba pristupa: nova kultura hiperkapitalizma u kojoj je cijeli život iskustvo za koje se plaća, Zagreb: Bulaja naklada.

Vidović, I. (2006.), Oglašavanje je modus vivendi. Epoha. Časopis za kulturu komuniciranja, 62: 18-21.

Zamyatin, Y. (1972.). We, New York: Bantam. 
DRUŠ. ISTRAŽ. ZAGREB GOD. 20 (2011), BR. 2 (112)

STR. $541-560$

DUJMOVIĆ, $M$. VRTLOG NOVOGA...

\section{Turbulent New World}

\author{
Mauro DUJMOVIĆ \\ Juraj Dobrila University of Pula, Pula
}

Aldous Huxley wrote Brave New World in 1932 while George Orwell wrote Nineteen Eighty-Four between 1945 and 1948. Aldous Huxley and George Orwell's anti-utopian novels share many similar features and thanks to their prophecies of the future of society, they are regarded as dystopian novels par excellence. Huxley and Orwell understood the danger and influence of the mass media over people and marked this event in different ways. In Brave New World, the influence of the media over people was so corroding that citizens inadvertently used advertising sentences in their speech. Orwell adopted the "telescreens" and drew attention to their obsessive presence in every citizen's life in Oceania: there, people were obliged to listen carefully to the instructions coming out of the video. The paper does not only compare the fictional worlds of 1984 and Brave New World, but also deals with consumption as a way of contemporary life and the influence of mass media on the development of consumer mentality. The paper is a verification of the hypothesis that mass media are the creators of utopian and magical reality associated with consumer goods for the purpose of strengthening capitalism and consumer society.

Keywords: media, consumption, technology, modern society, technological progress

\section{Turbulente neve Welt}

Mauro DUJMOVIĆ

Juraj Dobrila-Universität in Pula, Pula

Aldous Huxley verfasste 1932 seinen Roman Schöne neue Welt, George Orwells Roman 1984 entstand zwischen 1945 und 1948. Zu den Hauptmerkmalen dieser Werke gehören tiefste Verzweiflung, Pessimismus und die

Perspektivenlosigkeit der menschlichen Gegenwart und Zukunft. Beide Autoren warnen vor einem weltweiten massiven Verlust der Menschlichkeit, der uns zu seelenlosen Robotern degradiert, ohne dass wir uns dessen bewusst wären, sollte im Verlauf der Menschheitsgeschichte und der gesellschaftlichen Entwicklung keine Änderung eintreten. In Huxleys Roman Schöne neue Welt wird der Einfluss der Medien sehr deutlich: Die Menschen verwenden selbst im privaten Umgang miteinander die Sprache der Werbung. Orwell antizipierte die zentrale Stellung, die das Fernsehen im Haushalt einnehmen würde, und sagte voraus, dass 
DRUŠ. ISTRAŽ. ZAGREB GOD. 20 (2011)

BR. 2 (112)

STR. $541-560$

DUJMOVIĆ, $M$

VRTLOG NOYVOGA...
Instrument der Indoktrinierung und gesellschaftlichen Kontrolle avancieren würde. Außer den Ähnlichkeiten der beschriebenen fiktiven Welten in Orwells 1984 und Huxleys Schöne neue Welt thematisiert dieser Artikel den Konsum als die Lebensweise der modernen Gesellschaft und den Einfluss der Massenmedien auf die Entwicklung der Verbrauchermentalität. Abschließend kann die

Grundannahme bestätigt werden, dass die Massenmedien eine utopische und magische Realität herstellen, diese mit Waren in Verbindung zu bringen trachten und somit dem Kapitalismus und der Konsumgesellschaft den Rücken stärken.

Schlüsselbegriffe: Medien, Konsum, Technologie, moderne Gesellschaft, technologischer Fortschritt 